\title{
THE POWER OF THE MERGINS IN BUCHI EMECHETA'S IN THE DITCH AND KEHINDE
}

\author{
Márcia Aparecida Vilaça*
}

RESUM0:

\begin{abstract}
Este artigo analisa o poder das margens como terceiro espaço nos romances In the Ditch $e$ Kehinde da escritora nigeriana Buchi Emecheta. É neste espaço que as personagens Adah $e$ Kehinde aprendem a negociar e redefinir códigos sociais $e$ culturais assim como questões de gênero.

PALAVRAS-CHAVE: maleabilidade, território, casa, questões de gênero, negociação.
\end{abstract}

In the scope of literature in English produced by black writers, the works of the Nigerian novelist Buchi Emecheta deserve careful reading. She peoples her stories with female characters stripped from the idealization that we are bound to find in Chinua Achebe's Things Fall Apart (1958), for instance, where the female figures play supporting roles to the male characters. Therefore, her books offer the reader an interesting view of the social and cultural struggles experienced by women in their Nigerian homeland as well as in the foreign territory of England. This article focuses on two of Emecheta's characters: Adah Obi from In the Ditch (1972), and Kehinde 0kolo from Kehinde (1984). In common, they have their African origin, and the fact that they have moved to England to be with their husbands. They also go through similar, but not identical, processes of self-discovery.

The question of power and territory is crucial to the understanding of the cultural conflicts faced by the individuals who live in postcolonial countries, and who have dislocated from their homelands into the space of the former colonizer.

* Mestre em Letras: Estudos Literários (Área de concentração: Literaturas de Expressão Inglesa), 2003. 


\section{EMTESE}

Belo Horizonte, v. 8, p. I-243, dez. 2004

In the new environment, these individuals have to deal with situations that involve the controversial notions of margin and center. From this point of view, the marginal space could be described as an area of limited possibilities of action for the individual who inhabits this sphere. However, Emecheta's protagonists manage to deconstruct this negative concept of the margins.

Adah's tale takes place in London, where she wants to find a decent place for herself and her five children after having abandoned her violent husband. Kehinde Okolo and her husband Albert have lived in London for eighteen years. Kehinde has a job in a bank while Albert works in a store. It is also in London that their children Joshua and Bimpe were born. Different from Adah, Kehinde goes back to Nigeria - once more, after her husband - and this return to her homeland leads her to understand that she can no longer readapt to that way of life that used to be hers.

The third space that both Adah and Kehinde manage to reshape for themselves goes beyond geographical delimitations. Actually, it becomes much more a personal location for these fictional women. It is a space that they accomplish to reshape in the immigrant community to which they belong, as they learn to deal with different social codes and cultural traditions of both their West African origin and the European society where they now are.

In such a context, the house turns out to be one of the most meaningful elements in the novels. For those who have moved away from their native lands into foreign territories, the house becomes more than a building, a physical demarcation of their space in the communities to which these individuals belong. It becomes their home, the place where they feel comfortable, where they can be themselves. In immigrant communities, the house can be seen as a limit that, in a sense, separates its alien inhabitants from their new neighbors. In the case of Emecheta's novels, the walls of this house determine the conquered territory of the West Africans who have settled in European soil.

Looked at from this perspective, the house can be seen as the arena of those people that Homi Bhabha defines as the in-between individuals (1984: 2): people who have experienced distinct social and cultural realities and, therefore, find themselves split between two worlds, belonging at once to both and to neither 
of them. I regard the individuals who live in these communities as people who are restricted by an invisible yet powerful barbed-wired fence, and they can either accept the confinement and live within these limits or try to overcome them.

The image of the fence is reinforced by the narrator's description of the barbed wire on the windows of the ground floor apartments in the Pussy Cat Mansions, to where Adah is sent with her children. The narrator says that "the barbed wire was meant to protect the glass from the boys' ball smashing it, but the picture it gave was that of condemnation, unwantedness and death" (Emecheta, 1972: 16). However, the fence that Adah and Kehinde have to handle is made up of the social and cultural differences of the two worlds that they have inhabited. In order to deal with this invisible fence, Adah and Kehinde learn to be flexible, which does not mean mere acceptance of social and cultural codes. Instead, they learn to redefine and reshape those that will fit them in their new sphere thus refusing those that do not fit. Therefore, the house in the foreign territory transcends into these women's third space as they become more and more aware of their possibilities as individuals.

In her attempts at finding a decent place for herself and her children, Adah is rehoused twice. In the beginning of In the Ditch, she and her kids live in a very uncomfortable room under the tyranny of a Nigerian landlord who does not respect her. According to the narrator, "unfortunately for Adah, she was black, separated from her husband and, with five kids all under six, there were few landlords who would dream of taking her into their homes" (Emecheta 1972: 2). From this quotation, I believe that it is possible to infer that, even far from her native land, this black woman still has to bear with the patriarchal hierarchy of her tradition that ranks woman below man.

Adah leaves this place and is sent to the Pussy Cat Mansions, a complex of apartments for immigrant families. Here, she meets Carol, a social worker who is responsible for relocating the people who inhabit this building. Although Carol is a friendly person, I take her to stand for the male domination over the woman since she is the one who chooses when and where someone is going to move out of the Mansions. The house, thus, also becomes what Gayatri Spivak defines as an arena where "the ideological construction of gender" (1988: 287) takes place. Spivak 


\section{EMTESE}

Belo Horizonte, v. 8, p. I-243, dez. 2004

argues that the constriction of the woman in postcolonial societies is characterized by the "double effacement" of the female element: because she is a woman, and because she belongs to a group of people who were once colonized, she is twice silenced.

If Adah comes across a woman who wants to silence her, Kehinde also has to go through a similar experience, but in Nigerian soil. In her return to Lagos, after living in London for eighteen years, Kehinde finds herself in the uncomfortable position of the first wife of a man who has chosen to follow the polygamous tradition of their native culture. However, the role of oppressor is taken up by Kehinde's sister-in-law Mama Kaduna, who seems pleased to show Kehinde how a good woman is supposed to behave according to their Igbo set of codes. For example, when the family goes to visit Bimpe and Joshua in the boarding school where they are, Mama Kaduna makes Kehinde sit in the rear with Albert's second wife and the maid. So she tells Kehinde that "when we, relatives of the head of the family are here, we take the place of honor" (Emecheta, 1984: 88). In my point of view, the woman's words illustrate the position of the female element in that reality: a position of total subordination to those who represent the male authority.

If she is to remain in Nigeria, Kehinde will have to readapt again to the constraining codes that she was taught by her cultural tradition but that she can no longer take for granted once she has had the chance of living a less restrictive way of life. Unable to erase the effects that her cross-cultural experience have left on her, Kehinde leaves her husband in Nigeria and returns to London to start a new life.

The house that belonged to the Okolos and that Kehinde was supposed to sell before she went to Lagos becomes her house, her personal territory. Now as she settles here, she is able to turn this house into her third space where she does not have to abide to social or cultural codes that she does not agree with. Therefore, when her son Joshua returns to London in order to study, he is met by someone who he does not recognize as his good old mother. First, she refuses to give him the house, as he believed she was going to do. She makes it clear that the house is hers. He is also shocked by her relationship with Michael Gibson, her Caribbean tenant.

When confronted by her son because of her attitude, Kehinde makes it clear that "mothers are people too (...). I just don't have the energy to be the 
carrier of everybody's burdens any more" (Emecheta, 1984 : 139). Through her words, it is possible to perceive that this female character has also accomplished the difficult task of acknowledging that being a mother might be one of the roles of the woman in a society, but it is not the only one. The fact that a woman has children does not erase the fact that she is a woman.

Although Adah does not take a boyfriend, she also changes in her interactions with men, especially black men, after she moves out of the Pussy Cat Mansions, a decision that she takes against the will of Carol. "She had learned from experience not to rebuff men of her own race" (Emecheta, 1972: 134), which leads her to return the greetings of black men on the street, something that she did not use to do.

Adah and Kehinde manage to define their own third space, a territory where the invisible barbed-wired fence that I mentioned before is going to be undone and the strands that make it will be rearranged in such a way as to accommodate the redefined and reshaped social and cultural codes that guide these women. Yet, it must be noted that their processes are individual and cannot be taken to symbolize the transformations undergone by black female individuals in general. Contrasting with Adah's and Kehinde's attitudes in the novel In the Ditch we find, for example, the social worker Carol who just plays the role of the oppressor. In Kehinde we find Moriammo, the protagonist's best friend who also lives in London but remains submissive to the authority of her husband to the point of breaking up her friendship with Kehinde because he forces her to do so.

Anyway, I believe that, through her characters Adah and Kehinde, Emecheta presents a new literary perspective for the study of black female characters. At the same time, she invests the concept of the margins with a more productive, less negative meaning as she turns it into the arena of redefinition, negotiation and reshaping of distinct social and cultural codes. 


\section{EM TESE}

Belo Horizonte, v. 8, p. I-243, dez. 2004

ABSTRACT :

The article analyzes the power of the margins as a third space in the novels In the Ditch and Kehinde, by the Nigerian novelist Buchi Emecheta. It is in this space that the characters Adah and Kehinde learn to negotiate and redefine social and cultural codes as well as gender roles.

KEY WORDS: malleability, territory, house, gender roles, negotiation.

\section{REFERÊNCIAS BIBLIOGRÁFICAS}

ACHEBE, Chinua. "Things Fall Apart". 1958. In: Achebe, Chinua. The African Trilogy. London: Picador, 1988. p. 13-168.

BHABHA, Homi. The Location of Culture. London and New York: Routledge, 1994.

EMECHETA, Buchi. In the Ditch. Oxford: Heinemann, 1972. EMECHETA, Buchi. Kehinde. Oxford: Heinemann, 1984.

SPIVAK, Gayatri Chakravorty. "Can the Subaltern Speak?". In: Nelson, Cary and Lawrence Grossberg (eds.) Marxism and the Interpretation of Culture. London: Macmillan, 1988. p. 271-313. 